\title{
SLAUGOS STUDIJŲ STUDENTŲ PASIRYŽIMAS SLAUGYTI UŽSIKRE்TUSIUS ŽMOGAUS IMUNODEFICITO VIRUSU IR/AR SERGANČIUS İGYTU IMUNODEFICITO SINDROMU
}

\author{
Armida Andziuliené $\dot{e}^{1,2}$, Vida Mockien $\dot{\mathbf{e}}^{2}$ \\ ${ }^{1}$ Klaipèdos jūrininku ligonine, ${ }^{2}$ Klaipédos universitetas
}

Raktažodžiai: ŽIV/AIDS, slaugos studijų studentai, pasiryžimas slaugyti.

\begin{abstract}
Santrauka
Slaugytojai vis dažniau susiduria su ŽIV užsikrètusiais ir/ar AIDS sergančiais pacientais, todèl svarbu analizuoti ir slaugos studijų studentų, kaip būsimujjų slaugytojų, nuomonę, kaip turima informacija ŽIV ir/ar AIDS klausimais sąlygoja jų baimes, elgseną, požiūrị bei pasiryžimą slaugyti. Tyrimo tikslas - išanalizuoti slaugos studijų studentų pasiryžimą slaugyti užsikrètusius ŽIV ir/ar sergančius AIDS pacientus. Tyrimo metodika. Atliktas kiekybinis tyrimas, naudojant standartizuotą klausimyną. Tyrimo imtị sudare 2014 lapkričio mèn. - 2015 m. sausio mèn. apklausti 113 pirmo - ketvirto kurso slaugos studijų studentai. Rezultatų analizei naudotas statistinis „SPSS 17 for Windows" paketas. Tyrimas atliktas laikantis etikos principų. Tyrimo rezultatai. Išanalizavus respondentų pasiryžimą slaugyti užsikrètusius ŽIV ir/ar sergančius AIDS pacientus nustatyta, kad daugiau nei pusė respondentų būtų pasiryžę padèti užsikrètusiems ŽIV ir/ar sergantiems AIDS pacientams, padètų pagimdyti moteriai infekuotai ŽIV ir/ar sergančiai AIDS. Tačiau tik 23 proc. respondentų būtų pasiryžę rūpintis šiais pacientais, jei ateityje būtų išsiaiškinta, jog ŽIV ir/ ar AIDS galima užsikrèsti ir tais būdais, kurie dabar ịvardijami kaip saugūs. Išvada. Pasiryžimą slaugyti slopina neigiamas požiūris ị šiuos pacientus socialiniais aspektais.
\end{abstract}

\section{İvadas}

Pastaruosius 20 metų žmogaus imunodeficito viruso (toliau ŽIV) ir/ar igyto imunodeficito sindromo (toliau AIDS) epidemija lieka vienas iš didžiausių visuomenès sveikatos iššūkių. Jungtinių Tautų Organizacijos duomenimis, 2010 metų pabaigoje pasaulyje buvo apie 34 milijonai ŽIV, infekuotų žmonių [7], o šiuo metu - 36.7 milijonai [14]. Nuo epidemijos pradžios apie 60 milijonų žmonių buvo užsikrètę ŽIV ir apie 20 milijonų mire. Du trečdaliai visų ŽIV, infekuotų žmonių gyvena ị pietus nuo Sacharos Afrikoje. Per pastaruosius dvejus metus žmonių, gyvenančių su ŽIV skaičius padidejjo [16]. ŽIV infekcijos mastai nemažeja ir Baltijos jūros regione: 2010 metais Suomijoje buvo apie 2200, Estijoje daugiau nei 5000 ir Lietuvoje 3300 žmonių, gyvenančių su ŽIV ir/ar AIDS. Estija pirmauja tarp Baltijos regiono šalių naujų atvejų skaičiumi tarp suaugusiuju [13]. ŽIV epidemija Lietuvoje pasiekè reikšmingą lygį ir yra koncentruota tarp švirkščiamųjų narkotikų vartotojų. Nors Lietuvoje švirkščiamujų narkotikų vartotojams teikiamos kai kurios su ŽIV susijusios paslaugos, jų nepakanka epidemijai šalyje stabdyti [3]. Iki 2017 m. sausio 1 d. Lietuvoje ŽIV infekcija diagnozuota 2749 asmenims, iš kurių daugumą 79,4 proc. (2182 atv.) sudaro vyrai ir keturis kartus mažiau moterų 20,6 proc. (567 atv.) [15].

Žmonių, gyvenančių su ŽIV ir/ar AIDS, stigmatizavimas sveikatos priežiūros aplinkoje kelia rimtų problemų [2] ir ypač jei stigma išreikšta aiškiai. Tuomet stigma ženkliai daro ittaką aplinkinių elgesiui, prižiūrint sergančiuosius [6]. Nors Lietuva propaguoja lygybės ir nediskriminavimo principus, jų nesilaikoma įvairiais būdais [3]. Žmonès, užsikrètę ŽIV ir/ ar sergantys AIDS, jaučiasi diskriminuojami ir persekiojami visuomenès. Socialinè atskirtis pasireiškia darbo ir šeimos netektimi. Be to, pastebima, kad pacientus diskriminuoja ir stigmatizuoja medikų visuomene [11]. Diskriminuojami ir stigmatizuojami žmonès patiria didelị visuomenès spaudimą, gèdą, o tai susiję su neigiamais padariniais sveikatai [17].

V. Mockienè ir kt. [8] nurodo, jog slaugytojai vis dažniau susiduria su ŽIV užsikrètusiais ir/ar AIDS sergančiais pacientais. Dèl menko ŽIV priežiūros paslaugų finansavimo trūksta mokymų šiuo aspektu. Slaugytojai vaidina svarbų vaidmenį kovoje su ŽIV ir/ar AIDS, teikdami priežiūrą žmonėms, gyvenantiems su ŽIV ir/ar AIDS, tačiau susiduria su dideliu profesinès rizikos iššūkiu - infekcijos rizika. Žinios apie ŽIV yra labai svarbios slaugytojams ir akušeriams, kadangi tai keičia jų elgesị. Kiekvienas profesionalus slaugytojas turètų 
dèti visas pastangas, kad sergantis AIDS ir/ ar užsikrètęs ŽIV pagal galimybes būtų grąžintas ị visuomenę ir šeimą [2].

Medikai yra mokomi apie ŽIV, bet stereotipinès nuostatos yra neretai stipresnès nei turima tiksli informacija apie ŽIV. Gydytojai ar slaugytojai, susidūrę su ŽIV užsikrètusiu asmeniu, vis dar neretai elgiasi neprofesionaliai, žemindami ir ŽIV užsikrètusio asmens žmogiškaji, ir medikų profesinès bendruomenès profesini orumą [4]. Priešiškumo ir baimès jausmą užsikrèsti slaugytojams sukelia žinių stygius apie ŽIV ir/ar AIDS [2].

Žinant tai, kokias reakcijas patiria jau dirbantys sveikatos priežiūros darbuotojai, tampa aktualu išsiaiškinti ne tik slaugytojų, bet ir analizuoti slaugos studijų studentų, kaip būsimujjų slaugytojų, nuomonę, kaip turima informacija ŽIV

1 lentelè. Respondentų sociodemografiniai rodikliai

\begin{tabular}{|l|c|}
\hline \multicolumn{1}{|c|}{ Rodikliai } & N (proc.) \\
\hline Lytis & $4(3,5 \%)$ \\
\hline Vyrai & $109(96,5 \%)$ \\
\hline Moterys & \\
\hline Amžius & $42(37,2 \%)$ \\
\hline $18-19$ metų & $43(38,0 \%)$ \\
\hline $20-21$ metų & $15(13,3 \%)$ \\
\hline $22-23$ metų & $13(11,5 \%)$ \\
\hline 24 metų ir daugiau & \\
\hline Socialinè padėtis & $79(69,9 \%)$ \\
\hline Studijuoja & $34(30,1 \%)$ \\
\hline Studijuoja ir dirba & \\
\hline Gyvenamoji vieta & $83(73,5 \%)$ \\
\hline Miestas & $12(10,6 \%)$ \\
\hline Miestelis & $17(15,0 \%)$ \\
\hline Kaimas & $1(0,9 \%)$ \\
\hline Vienkiemis & \\
\hline Seksualinis aktyvumas & $76(67,3 \%)$ \\
\hline Pastovūs santykiai & $8(7,1 \%)$ \\
\hline Atsitiktiniai santykiai & $29(25,7 \%)$ \\
\hline Be santykių & \\
\hline
\end{tabular}

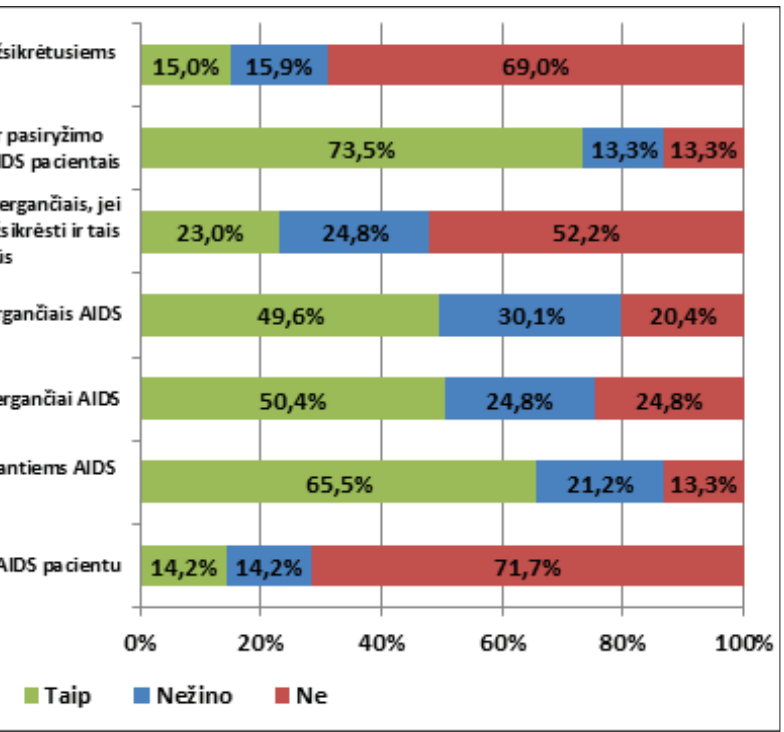

Taip $\square$ Nežino $\quad \mathrm{Ne}$

ir/ar AIDS klausimais sąlygoja jų baimes, nerimą, elgseną bei pasiryžimą slaugyti užsikretusius ŽIV ir/ar sergančius AIDS asmenis. Svarbu išsiaiškinti neturinčių patirties būsimujų specialistų žinių apie ŽIV ir/ar AIDS spragas ir jas papildyti. Taip pat svarbu žinoti slaugos studentų nuomonę apie ŽIV ir/ar AIDS, kad būtų galima formuoti tinkamą požiūrį ir išvengti užsikrètusių ŽIV ir/ar sergančių AIDS diskriminavimo.

Tyrimo tikslas - išanalizuoti slaugos studijų studentụ pasiryžimą slaugyti užsikrètusius ŽIV ir/ar sergančius AIDS.

\section{Tyrimo medžiaga ir metodas}

Tyrimas 2014 m. lapkričio / 2015 m. sausio mèn. atliktas viename iš Lietuvos universitetų. Tiriamųjų grupę sudare 1 - 4 kurso slaugos bakalauro programos studentai imtinai. Tyrime dalyvavo 113 slaugos studijų studentų (1 lentelè).

Tyrimo instrumentas sudarytas iš dviejų dalių: 1 dalis klausimai vertinti tyrimo dalyvių sociodemografinius duomenis: lytis, amžius, socialiné padètis, gyvenamoji vieta, kursas. Taip pat pateikti klausimai apie: seksualini aktyvumą, savo žinių apie ŽIV ir/ar AIDS vertinimą. Buvo klausiama, ar pažinojo užsikrètusi ŽIV ir/ar sergantiji AIDS, ar jų yra prašę slaugyti užsikrètusį ŽIV ir/ar sergantiji AIDS. 2 dalis - M. A. Abolfotouh ir bendraautorių [9] standartizuotas „Pasiryžimo slaugyti užsikrètusius ŽIV ir/ar AIDS sergančius pacientus“ klausimynas, siekiant atskleisti studentų pasiryžimą slaugyti pacientus, užsikrètusius ŽIV ir/ar sergančius AIDS. Darbe naudojamo klausimyno vidinis patikimumas buvo pakankamas Kronbacho (Cronbach) alfa $>0,70$ ).

Rezultatų analizei naudotas statistinis „SPSS 17 for Win- 
dows" paketas. Tikrintas intervalinių požymių pasiskirstymas pagal normalųj dèsnị taikant Kolmogorovo-Smirnovo (KolmogorovSmirnov) testą. Požymių turinčių normalųjị pasiskirstymą vidurkių palyginimui tarp dviejų nepriklausomų grupių naudotas neporinis Stjudento (Student) t kriterijus, o nesant normaliam pasiskirstymui ir mažoms imtims $(\mathrm{n}<30)$ neparametrinis Mano-Vitney (MannWhitney) kriterijus. Dviejų skirtingų požymių toje pačioje grupejje naudotas porinis Stjudento (Student) $t$ kriterijus, o nesant normaliam pasiskirstymui ir mažoms imtims $(\mathrm{n}<30)$ - neparametrinis Vilkoksono (Wilcoxon) kriterijus. Skirtumams tarp daugiau nei dviejų grupių vertinti, esant normaliam pasiskirstymui taikytas ANOVA metodas su LSD kriterijumi, nesant normaliam - Kruskalio-Voliso (Kruskal-Vallis) kriterijus. Ryšiams tarp kategorinių požymių bei intervalinių požymių (nesant normaliam pasiskirstymui) nustatyti naudotas Spirmeno (Spearmen) koreliacijos (r koeficientas) metodas. Siekiant nustatyti priežastinius ryšius tarp pasiryžimo slaugyti užsikrètusius ŽIV ir/ar AIDS sergančius pacientus ir žinių apie ŽIV ir/ar AIDS bei požiūrio ị šiuos pacientus, buvo atlikta daugialypès tiesinès regresijos analizè.

2 lentelè. Slaugos studijų studentų mokymosi trukmès, socialinès padèties, gyvenamosios vietos ir seksualinio aktyvumo įtaka pasiryžimui slaugyti užsikrètusius ŽIV ir/ar AIDS sergančius pacientus ns - statistiškai nereikšmingas ryšis

\begin{tabular}{|l|l|l|l|l|l|l|l|l|}
\hline \multirow{2}{*}{ Veiksniai } & \multicolumn{2}{|l|}{ Kursas } & \multicolumn{2}{|l|}{$\begin{array}{l}\text { Socialinė } \\
\text { padėtis }\end{array}$} & \multicolumn{2}{|l|}{$\begin{array}{l}\text { Gyvena- } \\
\text { moji vieta }\end{array}$} & \multicolumn{2}{|c|}{$\begin{array}{l}\text { Seksualinis } \\
\text { aktyvumas }\end{array}$} \\
\cline { 2 - 8 } & r & $\mathbf{p}$ & $\mathbf{r}$ & $\mathbf{p}$ & $\mathbf{r}$ & $\mathbf{p}$ & $\mathbf{r}$ & $\mathbf{p}$ \\
\hline $\begin{array}{l}\text { Būtu pasiryžę atlikti } \\
\text { burna ị burną gaivi- } \\
\text { nimą pacientams už- } \\
\text { sikrètusiems ŽIV ir/ } \\
\text { ar sergantiems AIDS }\end{array}$ & $\mathbf{- 0 , 2 6}$ & $\mathbf{0 , 0 0 6}$ & $-0,06$ & ns & 0,03 & ns & 0,01 & ns \\
\hline
\end{tabular}

3 lentelè. Žinių apie ŽIV ir/ar AIDS priežastis, prigimtị ir perdavimo būdus turèjimo sąsajos su pasiryžimu slaugyti užsikrètusius ŽIV ir/ar AIDS sergančius pacientus

$n s-$ statistiškai nereikšmingas ryšis

\begin{tabular}{|l|c|c|c|c|c|c|}
\hline \multirow{2}{*}{ Veiksniai } & \multicolumn{2}{|c|}{$\begin{array}{c}\text { Žinios apie } \\
\text { ŽIV ir/ar } \\
\text { AIDS prie- } \\
\text { žastis }\end{array}$} & $\begin{array}{c}\text { Žinios apie } \\
\text { ŽIV ir/ar } \\
\text { AIDS pri- } \\
\text { gimti }\end{array}$ & \multicolumn{2}{|c|}{$\begin{array}{c}\text { Žinios apie } \\
\text { ŽIV ir/ ar } \\
\text { AIDS perda- } \\
\text { vimo būdus }\end{array}$} \\
\cline { 2 - 7 } & $\mathbf{r}$ & $\mathbf{p}$ & $\mathbf{r}$ & $\mathbf{p}$ & $\mathbf{r}$ & $\mathbf{p}$ \\
\hline $\begin{array}{l}\text { Pasiryžę rūpintis pacientais } \\
\text { užsikretusiais ŽIV ir/ar ser- } \\
\text { gančiais AIDS }\end{array}$ & 0,03 & $\mathrm{~ns}$ & 0,04 & $\mathrm{~ns}$ & $\mathbf{0 , 1 9}$ & 0,044 \\
\hline $\begin{array}{l}\text { Būtu pasiryže padėti užsi- } \\
\text { krettusiems ŽIV ir/ar ser- } \\
\text { gantiems AIDS pacientams }\end{array}$ & $-0,03$ & $\mathrm{~ns}$ & 0,18 & $\mathrm{~ns}$ & 0,23 & 0,017 \\
\hline $\begin{array}{l}\text { Būtu pasiryžę atlikti burna } \\
\text { i burną gaivinimą pacien- } \\
\text { tams, užsikrėtusiems ŽIV } \\
\text { ir/ar sergantiems AIDS }\end{array}$ & 0,20 & 0,034 & 0,10 & $\mathrm{~ns}$ & $\mathbf{0 , 2 3}$ & 0,015 \\
\hline
\end{tabular}

Naudoti statistinių hipotezių reikšmingumo lygmenys: kai $\mathrm{p}<0,05\left(^{*}\right)$ - reikšmingas, kai $\mathrm{p}<$ $0,01(* *)$ - labai reikšmingas, kai $\mathrm{p}<0,001(* * *)$ - itin reikšmingas ir $\mathrm{p}>0,05$ (ns) - statistiškai nereikšmingas.

\section{Tyrimo rezultatai}

Išanalizavus respondentų pasiryžimą slaugyti užsikrètusius ŽIV ir/ar AIDS sergančius pacientus nustatyta, kad dauguma ( 73,5 proc.) respondentų mané, kad jų profesinis išsilavinimas suteiks pakankamai žinių ir pasiryžimo saugiam darbui su užsikrètusiais ŽIV ir/ar sergančiais AIDS pacientais. Daugiau nei pusè $(65,5$ proc.) respondentų būtų pasiryžę padèti užsikrètusiems ŽIV ir/ar sergantiems AIDS pacientams. Maždaug apie pusę respondentų būtų pasiryžę padèti pagimdyti moteriai, infekuotai ŽIV ir/ar sergančiai AIDS (50,4 proc.), bei pasiryžę rūpintis pacientais, užsikrètusiais ŽIV ir/ar sergančiais AIDS (49,6 proc.). Tačiau tik 23,0 proc. respondentų būtų pasiryžę rūpintis šiais pacientais, jei ateityje būtų išsiaiškinta, jog ŽIV ir/ar AIDS galima užsikrèsti ir tais būdais, kurie dabar ịvardijami kaip saugūs, 15,0 proc. - būtų pasiryžę atlikti burna ị burną gaivinimą tokiems pacientams ir 14,2 proc. - būtų ramūs rūpindamiesi užsikrètusiu ŽIV ir/ar sergančiu AIDS pacientu (1 pav.).

Pasiryžimo slaugyti užsikrètusius ŽIV ir/ar AIDS sergančius pacientus procentinis suminis vidurkis bendroje grupeje lygus $41,59 \pm 26,56$.

Nagrinėjant respondentų pasiryžimo slaugyti užsikrètusius ŽIV ir/ar AIDS sergančius pacientus atskirų aspektų sąsajas su mokymosi trukme, socialine ir darbine padètimi bei seksualiniu aktyvumu, nustatyta, kad respondentu pasiryžimas nepriklauso nuo socialinès ir darbinès padèties bei seksualinio aktyvumo. Analizuojant respondentų pasiryžimo slaugyti užsikrètusius ŽIV ir/ar AIDS sergančius pacientus, nustatyta, jog daugeliui respondentų pasiryžimo aspektų, išskyrus pasiryžimą atlikti burna i burną gaivinimą šiems pacientams, nepriklausè ir nuo mokymosi trukmès.

Nustatytas reikšmingas neigiamas ryšis tarp pasiryžimo atlikti burna ị burną gaivinimą ir mokymosi trukmès $(r=-0,26: p=0,006)$ parodè, kad vyresnių slaugos studijų kursų respondentai mažiau buvo pasiryžę atlikti toki gaivinimą, nei jaunesnių slaugos studijų kursų respondentai (2 lentelè).

Nagrinėjant respondentų pasiryžimo slaugyti užsikrètusius ŽIV ir/ar AIDS sergančius pacientus 
atskirų aspektų sąsajas su užsikrètusiojo ŽIV ir/ar sergančiojo AIDS pažinojimu bei prašymu slaugyti tokį asmenį, reikšmingų sąsajų nenustatyta.

Nustatyti reikšmingi $(p<0,05)$ teigiami ryšiai tarp žinių apie ŽIV ir/ar AIDS perdavimo būdus turejjimo ir tokių pasiryžimo slaugyti užsikrètusius ŽIV ir/ar AIDS sergančius pacientus aspektų kaip pasiryžimo padèti užsikrètusiems ŽIV ir/ar sergantiems AIDS pacientams $(r=0,23: p=0,017)$, pasiryžimo atlikti burna į burną gaivinimą pacientams užsikrètusiems ŽIV ir/ar sergantiems AIDS $(r=0,23: p=0,015)$ bei pasiryžimo rūpintis pacientais užsikretusiais ŽIV ir/ar sergančiais AIDS $(\mathrm{r}=0,19 \mathrm{p}=0,044)$. Gauti rezultatai parodè, kad respondentai, turintys daugiau žinių apie ŽIV ir/ ar AIDS perdavimo būdus, būtų labiau pasiryžę padèti užsikretusiems ŽIV ir/ar sergantiems AIDS pacientams atlikti burna ị burną gaivinimą jiems bei rūpintis jais, nei tie respondentai, kurie turejo mažiau tokių žinių. Nustatytas reikšmingas $(p<0,05)$ teigiamas ryšis tarp žinių apie ŽIV ir/ar AIDS priežastis turejjimo ir pasiryžimo atlikti burna ị burną gaivinimą pacientams, užsikrètusiems ŽIV ir/ar sergantiems AIDS $(r=0,20$ : $p=0,034)$ - respondentai, turintys daugiau žinių apie ŽIV ir/ar AIDS priežastis būtų labiau pasiryžę atlikti burna ị burną gaivinimą šiems pacientams, nei tie respondentai, kurie turèjo mažiau tokių žinių (3 lentelè).

Nustatytas reikšmingas $(\mathrm{p}<0,05)$ teigiamas ryšis tarp žinių apie ŽIV ir/ar AIDS rizikos grupes turèjimo ir nuomonès, kad profesinis išsilavinimas suteiks pakankamai žinių ir pasiryžimo saugiam darbui su užsikretusiais ŽIV ir/ar sergančiais AIDS pacientais $(r=0,24: p=0,011)$ - respondentai, turintys daugiau žinių apie ŽIV ir/ar AIDS rizikos grupès buvo linkę labiau manyti, kad jų profesinis išsilavinimas suteiks pakankamai žinių ir pasiryžimo saugiam darbui su šiais pacientais, nei tie respondentai, kurie turèjo mažiau tokių žinių. Bendras žinių apie ŽIV ir/ar AIDS rodiklis reikšmingai $(p<0,05)$ susijęs su tokiais pasiryžimo slaugyti užsikrètusius ŽIV ir/ar AIDS sergančius pacientus aspektais, kaip pasiryžimas atlikti burna į burną gaivinimą šiems pacientams $(\mathrm{r}=0,22$ : $\mathrm{p}=0,021)$ ir pasiryžimas jiems padèti $(\mathrm{r}=0,21 \mathrm{p}=0,028)$ - respondentai, turintys daugiau bendrai žinių apie ŽIV ir/ar AIDS būtų labiau pasiryžę atlikti burna ị burną gaivinimą bei padèti tokiems pacientams nei tie respondentai, kurie turèjo mažiau žinių apie ŽIV ir/ar AIDS (4 lentelè).
4 lentelè. Žinių apie ŽIV ir/ar AIDS gydymo kontrolę, rizikos grupes turèjimo bei apibendrinto žinių rodiklio sąsajos su pasiryžimu slaugyti užsikrètusius ŽIV ir/ar AIDS sergančius pacientus

ns - statistiškai nereikšmingas ryšis

\begin{tabular}{|c|c|c|c|c|c|c|}
\hline \multirow[t]{2}{*}{ Veiksniai } & \multicolumn{2}{|c|}{$\begin{array}{l}\text { Žinios apie } \\
\text { ŽIV ir/ } \\
\text { ar AIDS } \\
\text { gydymą/ } \\
\text { kontrolę }\end{array}$} & \multicolumn{2}{|c|}{$\begin{array}{l}\text { Žinios apie } \\
\text { ŽIV ir/ } \\
\text { arAIDS rizi- } \\
\text { kos grupes }\end{array}$} & \multicolumn{2}{|c|}{$\begin{array}{l}\text { Žinių apie } \\
\text { ŽIV ir/ } \\
\text { ar AIDS } \\
\text { apibend. } \\
\text { rodiklis }\end{array}$} \\
\hline & $\mathbf{r}$ & $\mathbf{p}$ & $\mathbf{r}$ & $\mathbf{p}$ & $\mathbf{r}$ & p \\
\hline $\begin{array}{l}\text { Būtų pasiryžę padèti užsi- } \\
\text { krètusiems ŽIV ir/ar ser- } \\
\text { gantiems AIDS pacientams }\end{array}$ & 0,05 & $\mathrm{~ns}$ & 0,06 & ns & 0,21 & 0,028 \\
\hline $\begin{array}{l}\text { Profesinis išsilavinimas } \\
\text { suteiks pakankamai žinių ir } \\
\text { pasiryžimo saugiam darbui } \\
\text { su užsikretusiais ŽIV ir/ar } \\
\text { sergančiais AIDS pacientais }\end{array}$ & $-0,02$ & $\mathrm{~ns}$ & 0,24 & 0,011 & 0,14 & ns \\
\hline $\begin{array}{l}\text { Būtu pasiryžę atlikti burna } \\
\text { i burną gaivinimą pacien- } \\
\text { tams, užsikretusiems ŽIV } \\
\text { ir/ar sergantiems AIDS }\end{array}$ & 0,05 & $\mathrm{~ns}$ & 0,16 & ns & 0,22 & 0,021 \\
\hline
\end{tabular}

5 lentelė. Požiūrio ị užsikrètusius ŽIV ir/ar AIDS sergančius pacientus socialiniais aspektais ir jų priežiūrą bei apibendrinto požiūrio rodiklio sąsajos su pasiryžimu slaugyti užsikrètusius ŽIV ir/ar AIDS sergančius pacientus ns - statistiškai nereikšmingas ryšis

\begin{tabular}{|c|c|c|c|c|c|c|}
\hline \multirow[t]{2}{*}{ Veiksniai } & \multicolumn{2}{|c|}{$\begin{array}{l}\text { Požiūris } \\
\text { socialiniais } \\
\text { aspektais }\end{array}$} & \multicolumn{2}{|c|}{$\begin{array}{c}\text { Požiūris i jụ } \\
\text { priežiūrą }\end{array}$} & \multicolumn{2}{|c|}{\begin{tabular}{|c|} 
Požiūrio \\
apibendrintas \\
rodiklis
\end{tabular}} \\
\hline & $\mathbf{r}$ & p & $\mathbf{r}$ & p & $\mathbf{r}$ & p \\
\hline $\begin{array}{l}\text { Būtų pasiryže padèti užsi- } \\
\text { krètusiems ŽIV ir/ar ser- } \\
\text { gantiems AIDS pacientams }\end{array}$ & $-0,37$ & $<0,001$ & 0,03 & ns & $\mid-\mathbf{0 , 3 1}$ & $\mathbf{0 , 0 0 1}$ \\
\hline $\begin{array}{l}\text { Būtų pasiryžę padėti pa- } \\
\text { gimdyti moteriai infekuotai } \\
\text { ŽIV ir/ar sergančiai AIDS }\end{array}$ & $-0,40$ & $<0,001$ & 0,03 & ns & $\mid-\mathbf{0 , 3 4}$ & $<0,001$ \\
\hline $\begin{array}{l}\text { Pasiryžę rūpintis pacientais, } \\
\text { užsikretusiais ŽIV ir/ar ser- } \\
\text { gančiais AIDS }\end{array}$ & $-\mathbf{0 , 3 0}$ & 0,001 & $-0,17$ & ns & $\mid-\mathbf{0 , 3 0}$ & $\mathbf{0 , 0 0 1}$ \\
\hline $\begin{array}{l}\text { Būtų pasiryžę rūpintis } \\
\text { pacientais, užsikrètusiais } \\
\text { ŽIV ir/ar sergančiais, nors } \\
\text { ateityje būtų išsiaiškinta, } \\
\text { jog ŽIV ir/ar AIDS galima } \\
\text { užsikrèsti ir tais būdais, } \\
\text { kurie dabar ịvardijami kaip } \\
\text { saugūs }\end{array}$ & $-0,19$ & 0,046 & $-0,02$ & ns & $\mid-0,17$ & ns \\
\hline $\begin{array}{l}\text { Būtų pasiryžę atlikti burna } \\
\text { i burną gaivinimą pacien- } \\
\text { tams, užsikretusiems ŽIV } \\
\text { ir/ar sergantiems AIDS }\end{array}$ & $-0,26$ & 0,005 & $-0,25$ & 0,008 & $-0,31$ & 0,001 \\
\hline
\end{tabular}


Nagrinėjant sąsajas tarp respondentų požiūrio ị užsikrètusius ŽIV ir/ ar AIDS sergančius pacientus ir pasiryžimo juos slaugyti nustatyti reikšmingi $(p<0,05)$ neigiami ryšiai tarp bendro požiūrio/požiūrio socialiniais aspektais ir tokiu veiksnių, kaip pasiryžimo padèti šiems pacientams $(\mathrm{r}=-0,31(\mathrm{p}=0,001) / \mathrm{r}=-0,37(\mathrm{p}<0,001)$, rūpintis jais $(\mathrm{r}=-0,30(\mathrm{p}=0,001) /$ $\mathrm{r}=-0,30(\mathrm{p}=0,001)$ bei padèti pagimdyti moteriai, infekuotai ŽIV/sergančiai AIDS $(r=-0,34(\mathrm{p}<0,001) / \mathrm{r}=-0,40(\mathrm{p}<0,001)$. Taip pat nustatyti reikšmingi $(p<0,05)$ neigiami ryšiai tarp bendro požiūrio/požiūrio socialiniais aspektais/požiūrio i jų priežiūrą ir tokių veiksnių kaip pasiryžimo

6 lentelè. Žinių ir požiūrio ị užsikrètusius ŽIV ir/ar AIDS sergančius pacientus apibendrintų rodiklių sąsajos su pasiryžimo slaugyti užsikrètusius ŽIV ir/ar AIDS sergančius pacientus apibendrintu rodikliu

*-nera normalaus skirstinio

\begin{tabular}{|l|c|c|}
\hline \multirow{2}{*}{ Rodikliai } & \multicolumn{2}{|c|}{ Pasiryžimas* } \\
\cline { 2 - 3 } & r & p \\
\hline Žinios & & \\
\hline $\begin{array}{l}\text { Žinios apie užsikrètusius ŽIV ir/ar AIDS sergančius pa- } \\
\text { cientus*: }\end{array}$ & 0,26 & $<0,006$ \\
\hline ŽIV ir/ar AIDS perdavimo būdai* & $-0,36$ & $<0,001$ \\
\hline Požiūris & \begin{tabular}{l}
$\mid$ \\
\hline $\begin{array}{l}\text { Požiūris ị užsikrètusius ŽIV ir/ar AIDS sergančius paci- } \\
\text { entus: }\end{array}$
\end{tabular} \\
\hline $\begin{array}{l}\text { Požiūris ị užsikrètusius ŽIV ir/ar AIDS sergančius pacientus } \\
\text { socialiniais aspektais* }\end{array}$ & $-0,38$ & $<0,001$ \\
\hline
\end{tabular}

7 lentelè. Mokymosi trukmès, žinių apie ŽIV ir/ar AIDS perdavimo būdus pakankamumo ir bendro požiūrio ị užsikretusius ŽIV ir/ar AIDS sergančius pacientus įtaka pasiryžimui slaugyti tokius pacientus

\begin{tabular}{|c|c|c|c|c|}
\hline \multirow{2}{*}{ Nepriklausomi rodikliai } & \multirow{2}{*}{$\mathbf{R}^{2}(\mathbf{p})$} & \multicolumn{3}{|c|}{\begin{tabular}{|l|} 
Priklausomas \\
rodiklis \\
Pasiryžimas \\
\end{tabular}} \\
\hline & & & & n \\
\hline Kursas & \multirow{3}{*}{$0,15(<0,001)$} & $-1,75$ & $-0,07$ & 0,425 \\
\hline $\begin{array}{l}\text { Žinios apie ŽIV ir/ar AIDS perdavimo bū- } \\
\text { dus }\end{array}$ & & 0,24 & 0,15 & 0,108 \\
\hline $\begin{array}{l}\text { Požiūris į užsikrètusius ŽIV ir/ar AIDS ser- } \\
\text { gančius pacientus (bendras rodiklis) }\end{array}$ & & $-0,54$ & $-0,31$ & 0,001 \\
\hline
\end{tabular}

8 lentelè. Mokymosi trukmės, žinių apie ŽIV ir/ar AIDS perdavimo būdus pakankamumo ir požiūrio ị užsikrètusius ŽIV ir/ar AIDS sergančius pacientus socialiniais aspektais ịtaka pasiryžimui slaugyti tokius pacientus

\begin{tabular}{|c|c|c|c|c|}
\hline \multirow{3}{*}{ Nepriklausomi rodikliai } & \multirow{3}{*}{$\mathbf{R}^{2}(\mathbf{p})$} & \multirow{2}{*}{\multicolumn{3}{|c|}{\begin{tabular}{|l|}
$\begin{array}{l}\text { Priklausomas } \\
\text { rodiklis }\end{array}$ \\
Pasiryžimas \\
\end{tabular}}} \\
\hline & & & & \\
\hline & & B & $\beta$ & p \\
\hline Kursas & \multirow{3}{*}{$0,18(<0,001)$} & $-2,10$ & $-0,09$ & 0,327 \\
\hline $\begin{array}{l}\text { Žinios apie ŽIV ir/ar AIDS perdavimo bū- } \\
\text { dus }\end{array}$ & & 0,24 & 0,15 & 0,100 \\
\hline $\begin{array}{l}\text { Požiūris į užsikrètusius ŽIV ir/ar AIDS } \\
\text { sergančius pacientus socialiniais aspektais }\end{array}$ & & $-0,50$ & $-0,35$ & $<0,001$ \\
\hline
\end{tabular}

atlikti burna į burną gaivinimą pacientams, užsikrètusiems ŽIV ir/ar sergantiems AIDS $(\mathrm{r}=-0,31(\mathrm{p}=0,001) / \mathrm{r}=-0,26(\mathrm{p}=0,005) / \mathrm{r}=-$ $0,25(\mathrm{p}=0,008))$. Gauti rezultatai parodè, kad respondentai, turintys neigiamesnị požiūrị i užsikrètusius ŽIV ir/ar AIDS sergančius pacientus, ypač susijusị su požiūriu socialiniais aspektais, buvo mažiau pasiryžę padèti šiems pacientams, rūpintis jais, padèti pagimdyti moteriai, infekuotai ŽIV ir/ar sergančiai AIDS, nei respondentai su teigiamesniu požiūriu. Be to, respondentai, turintys neigiamesnị požiūrị, susijusị ir su socialiniais aspektais ir su priežiūra, buvo mažiau pasiryžę atlikti burna ị burną gaivinimą, nei respondentai su teigiamesniu požiūriu. Pasiryžimas rūpintis pacientais, užsikrètusiais ŽIV ir/ar sergančiais, nors ateityje būtų išsiaiškinta, jog ŽIV ir/ar AIDS galima užsikrèsti ir tais būdais, kurie dabar ịvardijami, kaip saugūs reikšmingai $(\mathrm{p}<0,05)$ siejosi su požiūriu socialiniais aspektais $(r=-0,19: p=0,046)$, tačiau su bendru požiūriu reikšmingo ryšio nenustatyta - respondentai, turintys neigiamesnị požiūrị ị užsikrètusius ŽIV ir/ar AIDS sergančius pacientus socialiniais aspektais, būtų mažiau pasiryžę jais rūpintis, jei ateityje būtų išsiaiškinta, jog ŽIV ir/ar AIDS galima užsikrèsti ir tais būdais, kurie dabar ìvardijami kaip saugūs, nei respondentai su teigiamesniu požiūriu (5 lentelè).

Analizuojant žinių ir požiūrio ị užsikrètusius ŽIV ir/ar AIDS sergančius pacientus apibendrintų rodiklių sąsajas su pasiryžimo slaugyti tokius pacientus apibendrintu rodikliu, nustatytas reikšmingas teigiamas ryšis tarp žinių apie ŽIV ir/ar AIDS perdavimo būdus ir pasiryžimo slaugyti užsikrètusius ŽIV ir/ar AIDS sergančius pacientus ( $\mathrm{r}=0,26$ : $\mathrm{p}=0,006$ ), ir neigiami ryšiai tarp bendro požiūrio ị užsikrètusius ŽIV ir/ar AIDS sergančius pacientus/požiūrio socialiniais aspektais tarp pasiryžimo juos slaugyti $(\mathrm{r}=-0,36$ : $\mathrm{p}<0,001 / \mathrm{r}=-0,36: \mathrm{p}<0,001)$. Respondentai, turintys daugiau žiniu apie ŽIV ir/ar AIDS perdavimo būdus, buvo labiau pasiryžę slaugyti užsikrètusius ŽIV ir/ar AIDS sergančius pacientus, nei mažiau tokių žinių turintys respondentai. Tačiau respondentai labiau nusistatę prieš užsikrètusius ŽIV ir/ 
ar AIDS sergančius pacientus, ypač socialiniais aspektais, buvo mažiau pasiryžę slaugyti juos, nei respondentai mažiau nusistatę prieš tokius asmenis (6 lentelè).

Siekiant nustatyti priežastinius ryšius tarp pasiryžimo slaugyti užsikrètusius ŽIV ir/ar AIDS sergančius pacientus ir žinių apie ŽIV ir/ar AIDS perdavimo būdus turèjimo bei požiūrio ị šiuos pacientus, buvo atlikta daugialypès tiesinès regresijos analizè.

Analizuojant veiksnius, veikiančius respondentų pasiryžimą slaugyti užsikrètusius ŽIV ir/ar AIDS sergančius pacientus, buvo sudaryti 2 regresiniai modeliai (ENTER metodas), įtraukiant ị jị mokymosi trukmę, žinių apie ŽIV ir/ar AIDS perdavimo būdus ir atskirai po vieną bendrą požiūrị ị užsikrètusius ŽIV ir/ar AIDS sergančius pacientus bei požiūrị ị užsikrètusius ŽIV ir/ar AIDS sergančius pacientus socialiniais aspektais (7-8 lentelès).

Regresinio modelio, ị kurị buvo ịtrauktas bendras požiūris ị užsikretusius ŽIV ir/ar AIDS sergančius pacientus, determinacijos koeficientas $\mathrm{R}^{2}=0,15$. Tai reiškia, kad sudarytu regresijos modeliu galime apibendrinti apie 15,0 procentų duomenų. Kadangi paaiškinama dalis nèra itin didelè, iš to galima spręsti, kad pasiryžimą slaugyti užsikrètusius ŽIV ir/ ar AIDS sergančius pacientus lemia ir kiti veiksniai, kurie šiame tyrime netyrinèti.

Nustatyta, kad pasiryžimą slaugyti užsikrètusius ŽIV ir/ ar AIDS sergančius pacientus turi neigiamos įtakos nusistatymas prieš užsikrètusius ŽIV ir/ar AIDS sergančius pacientus. Mokymosi trukmė ir žinios apie ŽIV/AIDS perdavimo būdus reikšmingos įtakos pasiryžimui slaugyti užsikretusius ŽIV ir/ar AIDS sergančius pacientus neturi (7 lentelè).

Regresinio modelio, ị kurị buvo ịtrauktas požiūris ị užsikrètusius ŽIV ir/ar AIDS sergančius pacientus socialiniais aspektais, determinacijos koeficientas $\mathrm{R}^{2}=0,18$. Tai reiškia, kad sudarytu regresijos modeliu galime apibendrinti apie 18,0 procentų duomenų. Kadangi paaiškinama dalis nèra itin didele, iš to galima spręsti, kad pasiryžimą slaugyti užsikrettusius ŽIV ir/ar AIDS sergančius pacientus lemia ir kiti veiksniai, kurie šiame tyrime netyrinèti (8 lentelè).

Nustatyta, jog pasiryžimui slaugyti užsikrètusius ŽIV ir/ ar AIDS sergančius pacientus turi neigiamos įtakos nusistatymas prieš užsikrètusius ŽIV ir/ar AIDS sergančius pacientus socialiniais aspektais. Mokymosi trukmè ir žinios apie ŽIV ir/ar AIDS perdavimo būdus reikšmingos įtakos pasiryžimui slaugyti užsikrètusius ŽIV ir/ar AIDS sergančius pacientus neturi (8 lentelè).

Atsižvelgus ị šių modelių determinacijos ir $\beta$ koeficientu dydžius, galima daryti išvadą, kad pasiryžimui slaugyti užsikrètusius ŽIV ir/ar AIDS sergančius pacientus turi neigiamos įtakos požiūris ị šiuos pacientus socialiniais aspektais.

\section{Rezultatų aptarimas}

Išanalizavus respondentų pasiryžimą slaugyti užsikrètusius ŽIV ir/ar AIDS sergančius pacientus nustatyta, kad dauguma respondentų manè, kad jų profesinis išsilavinimas suteiks pakankamai žinių ir pasiryžimo saugiam darbui su užsikrètusiais ŽIV ir/ar sergančiais AIDS pacientais. Daugiau nei pusė respondentų būtų pasiryžę padėti užsikrètusiems ŽIV ir/ar sergantiems AIDS pacientams. Maždaug apie pusę respondentų būtų pasiryžę padèti pagimdyti moteriai infekuotai ŽIV ir/ar sergančiai AIDS bei pasiryžę rūpintis pacientais užsikrètusiais ŽIV ir/ar sergančiais AIDS. Tačiau tik dalis respondentų būtų pasiryžę rūpintis šiais pacientais, jei ateityje būtų išsiaiškinta, jog ŽIV ir/ar AIDS galima užsikrèsti ir tais būdais, kurie dabar ịvardijami kaip saugūs. A. Bahadur Gurung, B. Sangchart [1] tyrimo duomenimis, net 72 proc. slaugytojų labiau pasiryžę slaugyti kūdikį užsikrètusį ŽIV gimdymo metu, negu pacientą, kuris ŽIV užsikrète dèl narkotikų vartojimo. V. Nimma ir kt. [10] tyrimo duomenimis, 48 proc. apklausos dalyvių teige, kad jie neprivalo gydyti ŽIV ir/ ar AIDS pacientų, 36 proc. teigè, kad šie pacientai turètų būti gydomi atskirai nuo kitų pacientu. Nagrinèjant respondentų pasiryžimo slaugyti užsikrètusius ŽIV ir/ar AIDS sergančius pacientus atskirų aspektų sąsajas su mokymosi trukme, socialine ir darbine padètimi bei seksualiniu aktyvumu nustatyta, kad respondentų pasiryžimas nepriklauso nuo socialinès ir darbinès padèties bei seksualinio aktyvumo. O. Sehume, L. Zungu, M. Hoque [12] tyrimo rezultatai parodè, kad yra statistiškai reikšmingas ryšys tarp pasiryžimo slaugyti užsikrètusius ŽIV ir bandymo atlikti savo ŽIV testą po to, kai buvo netyčia infekuoti sergančiojo kūno sekretais $(p=0,0120)$.

Daugeliui pasiryžimo aspektų, išskyrus pasiryžimui atlikti burna ị burną gaivinimą šiems pacientams, nepriklausẻ ir nuo mokymosi trukmès. Nustatyti reikšmingi $(\mathrm{p}<0,05)$ teigiami ryšiai tarp žinių apie ŽIV ir/ar AIDS perdavimo būdus turẻjimo ir tokių pasiryžimo slaugyti užsikrètusius ŽIV ir/ar AIDS sergančius pacientus aspektų kaip pasiryžimo padèti užsikrètusiems ŽIV ir/ar sergantiems AIDS pacientams bei pasiryžimo rūpintis pacientais, užsikrètusiais ŽIV ir/ar sergančiais AIDS. Gauti rezultatai parodé, kad respondentai, turintys daugiau žinių apie ŽIV ir/ar AIDS perdavimo būdus, būtų labiau pasiryžę padèti užsikrètusiems ŽIV ir/ar sergantiems AIDS pacientams, atlikti burna ị burną gaivinimą jiems bei rūpintis jais, nei tie respondentai, kurie turèjo mažiau tokių žinių. O. Sehume, L. Zungu, M. Hoque [12] tyrimo metu nustatyta, kad 99,2 proc. studentų norètų slaugyti ŽIV teigiamus pacientus. Vidutiniškai apie 25 proc. respondentų mano, kad jaustųsi nepatogiai, jei reikètų kontaktuoti su asmeniu, užsikrètusiu ŽIV ir/ar sergančiu AIDS. Diskomfortas buvo siejamas su baime užsikrèsti. Baimè užsikrèsti tiesiogiai susijusi su nenoru slaugyti asmenis, užsikrètusius ŽIV ir/ar 
sergančius AIDS [5].

Nustatytas reikšmingas $(p<0,05)$ teigiamas ryšis tarp žinių apie ŽIV ir/ar AIDS priežastis turejjimo ir pasiryžimo atlikti burna ị burną gaivinimą pacientams, užsikrètusiems ŽIV ir/ar sergantiems AIDS - respondentai, turintys daugiau žinių apie ŽIV ir/ar AIDS priežastis būtų labiau pasiryžę atlikti burna ị burną gaivinimą šiems pacientams, nei tie respondentai, kurie turèjo mažiau tokių žinių. Gauti rezultatai parodè, kad respondentai, turintys neigiamesni požiūrị i užsikrètusius ŽIV ir/ar AIDS sergančius pacientus, ypač susijusị su požiūriu socialiniais aspektais, buvo mažiau pasiryžę padèti šiems pacientams, rūpintis jais, padèti pagimdyti moteriai, infekuotai ŽIV ir/ar sergančiai AIDS, nei respondentai su teigiamesniu požiūriu. A. Bahadur Gurung, B. Sangchart [1] tyrimo duomenimis, slaugytojų teigiamas požiūris į ŽIV ir/ar AIDS pacientus stipriai koreliavo su pasiryžimu slaugyti $(\mathrm{rs}=0,317, \mathrm{p}<0,01)$. Tai reiškia, kad slaugytojas su teigiamu požiūriu yra labiau linkęs slaugyti užsikretusį ŽIV ir/ar sergantị AIDS.

Šiuo atliktu tyrimu išsiaiškita, jog mokymosi trukmè ir Žinios apie ŽIV ir/ar AIDS perdavimo būdus reikšmingos įtakos pasiryžimui slaugyti užsikrètusius ŽIV ir/ar AIDS sergančius pacientus neturi. Pasiryžimui slaugyti užsikrètusius ŽIV ir/ar AIDS sergančius pacientus turi neigiamos įtakos požiūris ị šiuos pacientus socialiniais aspektais.

\section{Išvados}

1. Išanalizavus respondentų pasiryžimą slaugyti užsikrètusius ŽIV ir/ar AIDS sergančius pacientus nustatyta, kad daugiau nei pusė respondentų būtų pasiryžę padèti užsikrètusiems ŽIV ir/ar sergantiems AIDS pacientams.

2. Respondentų pasiryžimas nepriklauso nuo socialinès ir darbinès padeties bei seksualinio aktyvumo.

3. Mokymosi trukmė ir žinios apie ŽIV ir/ar AIDS perdavimo būdus reikšmingos įtakos pasiryžimui slaugyti užsikrètusius ŽIV ir/ar AIDS sergančius pacientus neturèjo.

4. Pasiryžimui slaugyti užsikretusius ŽIV ir/ar AIDS sergančius pacientus turi neigiamos ịtakos požiūris ị šiuos pacientus socialiniais aspektais.

\section{Literatūra}

1. Bahadur, Gurung A, Sangchart B. Nurse's knowledge, attitude and willingness to take care for HIV/AIDS patients in Bhutan. KKU Res J (GS) 2008; 8(3):53-64.

2. Chan KY, Stoové MA, Reidpath DD. Stigma, social reciprocity and exclusion of HIV/AIDS patients with illicit drug histories: a study of Thai nurses' attitudes. Harm Reduction Journal 2008;5(28):1 - 11 .

https://doi.org/10.1186/1477-7517-5-28
3. Eramova I, Joncheere K, Laukamm-Josten U, Mendao L, Rotberga S, Skarphedinsdottir R, Drew R. ŽIV ligos gydymo ir priežiuros prieinamumo Lietuvoje vertinimas. United Nations Office on Drugs and crime 2010; 40,47.

4. Higienos institutas prie Sveikatos apsaugos ministerijos. Kokybinis tyrimas dèl žmonių, užsikrètusių ŽIV /sergančių AIDS, pažeidžiamumo įvertinimo Lietuvoje. Vilnius, 2009:14-15.

5. Houtsonen J, Kylma J, Korhonen T, Valimaki M, Suominen T. University students' perception of people living with HIV/ AIDS: discomfort, fear, knowledge and a willingness to care. College Student Journal 2014:34-547.

6. Kiaunytė A, Dargytė I. ŽIV infekuotujų socialinio tinklo palaikymo aspektai. Sveikatos mokslai, 2010;5:3428.

7. Levickaite K., Lošakevičius A. ŽIV, AIDS ir psichikos sveikata. Psichikos sveikatos paslaugų prieinamumas ŽIV infekuotiems ir AIDS sergantiems asmenims Lietuvoje. Vilnius, 2012.

8. Mockienė V, Suominen T, Välimäki M, Razbadauskas A. Impact of intervention programs on nurses' knowledge, attitudes, and willingness to take care of patients with human immunodeficiency virus/acquired immunodeficiency syndrome: a descriptive review. Medicina 2010; 46(3):159-168.

9. Abolfotouh MA, Al Saleh SA, Mahfouz AA, Abolfotouh SM, Al Fozan HM. Attitudes of Saudi nursing students on AIDS and predictors of willingness to provide care for patients in Central Saudi Arabia. SAGE Open 2013:1-11.

https://doi.org/10.1177/2158244013499163

10. Nimma V, Lavanya R, Amara SL, Sudhakara R, Ramesh T, Padmareddy M. Are you willing to treat patients with HIV/ AIDS? - an anonymous survey among staff and students of dental institution. OHDM 2014;3:745 - 748.

11. Reis C, Heisler M, Amowitz LL, Moreland RS. Mafeni JO, Anyamele C, Iacopino V. Discriminatory attitudes and practices by health workers toward patients with HIV/AIDS in Nigeria. PLoS medicine 2005;2(8). https://doi.org/10.1371/journal.pmed.0020246

12. Sehume O, Zungu L., Hoque M. Attitudes and willingness of nursing students towards caring for patients infected with HIV in South Africa. Ife Psychologia 2012; 20(2):12.

13. Suominen T, Niina K, Mockiene V, Raid U, Istomina N. Vänskä ML, Blek-Vehkaluoto M, Välimäki M. Nurses' knowledge and attitudes to HIV/AIDS - an international comparison between Finland, Estonia and Lithuania. International Journal of Nursing Practice 2010;16:138 - 147. https://doi.org/10.1111/j.1440-172X.2010.01822.x

14. UNAIDS. 2016. Report on the global AIDS epidemic. Geneva.

15. Užkrečiamujjų ligų ir AIDS centras. 2016 metais ŽIV infekcija diagnozuota 214 asmenų. [žiūrèta $2017 \mathrm{~m}$. liepos 11d.].Prieiga per internetą: <http://www.ulac.lt/lt/naujienos/pranesimaispaudai/2016-metais-ziv-infekcija diagnozuota-214-asmenu>.

16. Välimäki M, Makkonen P, Blek-Vehkaluoto M, Mockiene V, Istomina N, Raid U, Vänskä M.L, Suominen T. Willingness to care for patients with HIV/AIDS. Nursing Ethics 
2008;15(5):586-600.

https://doi.org/10.1177/0969733008092868

17. Zukoski AP, Thorburn S. Experiences of stigma and discrimination among adults living with HIV in a low HIV-prevalence context: qualitative analysis. Aids patient care and STDs 2009;23(4):267.

https://doi.org/10.1089/apc.2008.0168

\section{NURSING STUDENTS KNOWLEDGE, ATTITUDES AND WILLINGNESS TO TAKE CARE FOR PATIENTS INFECTED WITH HUMAN IMMUNODEFICIENCY VIRUS AND / OR HAVING ACQUIRED IMMUNE DEFICIENCY SYNDROME}

\section{A. Andziulienė, V. Mockienė}

Key words: HIV/AIDS, nursing students, determination to take care.

\section{Summary}

Nursing staff more and more often face patients infected with HIV and/or having AIDS, therefore it is important to analyse the opinion of the future nursing staff -nursing students, on how the knowledge they have of HIV and/or AIDS conditions their fears, behaviour, attitude and the determination to take care. Objective of the research - to analyse nursing students determination to take care for patients infected with HIV and/or having AIDS. Research methodology. Quantitative research, using standartised questionnaire, has been carried out. Scope of the research - 113 first - fourthyear nursing students, questioned during the period of November 2014 - January 2015. Statistical package "SPSS 17 for Windows" has been used to analyse the results obtained. Research has been carried out following the principles of ethics. Results of the research. Analysis of the determination to take care for patients infected with HIV and/or having AIDS of the respondents has lead to a conclusion, that more than half of the respondents would be willing to take care for a patient infected with HIV and/or having AIDS, or help in the delivery for a woman who has been infected with HIV and/or having AIDS. However, only $23 \%$ of the respondents would be willing to take care for those patients, if in the future it would be discovered that the ways which are today identified as safe, in fact also hold the possibility to be infected with HIV and/or AIDS. Conclusion. Determination to care for those patients suffers from socially negative attitude towards patients infected with HIV and/or having AIDS.

Correspondence to: armida.andziuliene@gmail.com

Gauta 2017-09-08 